\title{
CHEMICAL CONSTITUENTS FROM ALGERIAN FOENICULUM VULGARE AERIAL PARTS AND EVALUATION OF ANTIMICROBIAL ACTIVITY
}

\author{
AMAR ZELLAGUI', NOUREDDINE GHERRAF', AHMED ELKHATEEB', MOHAMED-ELAMIR F. HEGAZY3,4*, \\ TARIK A. MOHAMED ${ }^{3}$, AHMED TOUIL ${ }^{1}$, ABDELAATY A. SHAHAT ${ }^{3}$, SALAH RHOUATI ${ }^{1}$
}

\author{
${ }^{\prime}$ Laboratory of Natural Products and Organic synthesis, Department of Chemistry, Faculty of Science, Mentouri - Constantine University, Algeria. \\ ${ }_{2}$ Phytochemistry and Plant Systematic Department, National Research Centre, El-Tahrir St., Dokki, Giza, 12622, Egypt. . \\ ${ }^{3}$ Chemistry and Medicinal Plants Department, National Research Centre, El-Tahrir St., Dokki, Giza, 12622, Egypt. \\ ${ }^{4}$ Pharmaceutical Laboratory, Center of Excellence for Advanced Sciences, National Research Center, El-Tahrir St Dokki 12622, Cairo, Egypt.
}

(Received: October 7, 2010 - Accepted: May 30, 2011)

\begin{abstract}
Phytochemical study of the aerial parts of Foeniculum vulgare led to the isolation of seven compounds isolated for the first time from this species. After isolation and purification, these metabolites were characterized on the basis of spectroscopic analyses using 1D and 2D NMR as well as mass spectrometry. Furthermore, antimicrobial activity of the crude extract was evaluated using agar diffusion method. The antimicrobial test results showed that the crude extract had a great potential as antimicrobial activity against all 9 microorganisms especially fungal strains.
\end{abstract}

Keywords: Foeniculum vulgare, Umbellifarae, menthane monoterpene derivative.

\section{INTRODUCTION}

There are growing interests, both in the industry and in the scientific research, for aromatic and medicinal plants because of their antimicrobial and antioxidant properties. These properties are due to many active phytochemicals including flavanoids, terpenoids, carotenoids, coumarins, curcumines, etc. These bioactive principles have also been confirmed using modern analytical techniques ${ }^{1-4}$. Hence, they are considered to be important in diets or medical therapies for biological tissue deterioration due to free radicals. Herbs and spices are amongst the most important targets to search for natural antimicrobials and antioxidants from the point of view of safety ${ }^{5,6}$. So far, many investigations on antimicrobial ${ }^{7-12}$ and antioxidant properties of spices volatile oils and extracts have been carried out.

Foeniculum vulgare Mill (Fam. Umbellifarae), commonly known as fennel, is a small genus of annual, biennial or perennial herbs distributed in central Europe and Mediterranean region which is used in traditional medicine and as spice. Herbal drug preparations, from numerous wild types, are active for dyspeptic complaints, bloating and flatulence ${ }^{13}$. Diuretic, analgesic and antipyretic activity has also been found in the fennel fruit ${ }^{14}$ as well as antioxidant activity ${ }^{15}$. It is widely cultivated throughout the temperate and tropical regions of the world for its aromatic fruits, which are used as a culinary spice ${ }^{14,16,17}$. Steam distillation of dried fruits yields an essential oil referred as "Fennel oil", used in western countries for flavouring purposes ${ }^{18}$. Although, the chemical constituents and antimicrobial properties of the fruit volatile oil of $F$. vulgare are well studied ${ }^{14,16,19-22}$, potential antimicrobial properties have not yet been studied for its aerial parts. The leaves and fruit are mainly used to flavour fish and meat, giving them a strong aroma and taste, and as an ingredient in cosmetics. The most frequently investigated was the essential oil which showed antioxidant, antimicrobial and hepatoprotective activity ${ }^{23,24}$. The chemical composition of the volatile oil fraction has been well described in the literature ${ }^{25-27}$. Earlier investigation of $F$. vulgare fruit led to the isolation of phenolic components with antihypertensive activity ${ }^{28,29}$. The target of this study was to isolate and characterize antimicrobial compounds from the earlier parts of $F$. vulgare.

\section{MATERIALS AND METHODS}

\subsection{GENERAL}

${ }^{1} \mathrm{H}$ NMR (500 MHz, $\left.\mathrm{CDCl}_{3}\right),{ }^{13} \mathrm{C} \mathrm{NMR}\left(125 \mathrm{MHz}, \mathrm{CDCl}_{3}\right)$ and 2D spectra were recorded on a JEOL Lambda 500 spectrometer, with TMS as an internal standard. EIMS and HREIMS were recorded on a JEOL SX102A mass spectrometer. IR spectra were recorded on a JASCO FT/IR-5300 spectrometer.
2.2 PLANT MATERIAL

F. vulgare aerial part were collected in March 2003 Ouargla, southeast of Algeria, and identified by Dr. Chahma Abdel- Majid, Department of biology, Ouargla university. A voucher specimen was kept at the Herbarium of Laboratory of natural products, Department of chemistry, Constantine University under the code Number ZA 102.

\subsection{EXTRACTION AND ISOLATION}

The air-dried powdered earlier parts $(1 \mathrm{Kg})$ of $F$. vulgare were extracted with $\mathrm{CH}_{2} \mathrm{Cl}_{2}-\mathrm{MeOH}(1: 1)$ at room temperature. The obtained extract was concentrated in vacuo to give a residue $(65 \mathrm{~g})$ which was fractionated by silica gel CC $(6 \times 120 \mathrm{~cm})$ and eluted with $n$-hexane $(3 \mathrm{~L})$, followed by a gradient of $n$ - hexane- $\mathrm{CH}_{2} \mathrm{Cl}_{2}$ up to $100 \% \mathrm{CH}_{2} \mathrm{Cl}_{2}$ and $\mathrm{CH}_{2} \mathrm{Cl}_{2}-\mathrm{MeOH}$ up to $15 \% \mathrm{MeOH}$ ( $2 \mathrm{~L}$ of each solvent mixture) with increasing the polarity. The $n$-hexane$\mathrm{CH}_{2} \mathrm{Cl}_{2}(1: 1)$ was pre-fractionated by CC using Sephadex LH-20 $(2 \times 40 \mathrm{~cm})$ and eluted with $n$-hexane- $\mathrm{CH}_{2} \mathrm{Cl}_{2}(7: 4)$ to give compound $8(80 \mathrm{mg}, 0.12 \%)$. The $n$-hexane- $\mathrm{CH}_{2} \mathrm{Cl}_{2}$ (2:3) fraction was chromatographed on a Sephadex LH$20(1 \times 30 \mathrm{~cm})$ and eluted with $n$-hexane- $\mathrm{CH}_{2} \mathrm{Cl}_{2}-\mathrm{MeOH}(7: 4: 0.25)$ to afford compounds 4 (60 mg, $0.092 \%)$ and $5(40 \mathrm{mg}, 0.062 \%)$, respectively. The $\mathrm{CH}_{2} \mathrm{Cl}_{2}(100 \%)$ fraction, was pre-fractionated by CC on Sephadex LH-20 (1 $\times 30 \mathrm{~cm}$ ) eluting with $n$-hexane- $\mathrm{CH}_{2} \mathrm{Cl}_{2}-\mathrm{MeOH}(7: 4: 0.5)$ to afford compounds 6 (30 mg, $0.046 \%), 7$ (45 mg, $0.069 \%)$ and 2 (35 mg, $0.054 \%)$. Further purification for the $\mathrm{CH}_{2} \mathrm{Cl}_{2}-\mathrm{MeOH}(1: 1)$ fraction using CC on Sephadex LH-20 $(1 \times 30 \mathrm{~cm})$ eluting with $n$-hexane- $\mathrm{CH}_{2} \mathrm{Cl}_{2}-\mathrm{MeOH}(7: 4: 0.25)$ led to the isolation of compounds 1 (65 mg, $0.1 \%)$ and $\mathbf{3}(55 \mathrm{mg}, 0.085 \%)$, respectively.

\subsection{MICROORGANISM}

All of the bacteria (standard strains; Escherichi coli ATCC 25922, Staphylococcus blanc ATCC 27853 were obtained from Bacteriology Laboratory Constantine Hospital University (C.H.U), and clinical strains:, Proteus merabilis, Proteus vulgaris, Staphylococcus epidemidis Staphylococcus saprophyticus) were obtained from Bacteriology Laboratory Constantine Hospital University (C.H.U), while the fungi Aspergillus versicolor, Aspergillus fumigates and Penicilium camemberti strains were isolated in microbiology laboratory, department of biology, Oum el Bouaghi University.

\subsection{ANTIMICROBIAL ASSAY}

The Antimicrobial assay was carried out on crude extract $\left(\mathrm{CH}_{2} \mathrm{Cl}_{2} / \mathrm{MeOH}\right.$ 1:1) using agar diffusion method ${ }^{30,31}$ against six human pathogenic bacteria, including Gram positive (S. epidermidis, S. saprophyticus, S. blanc ATCC 27853), Gram-negative bacteria (E. coli, P. mirabilis, P. vulgaris) and three fungal strains $A$. versicolor, A. fumigates and $P$. camemberti. 
The bacterial strains were first grown on Muller Hinton medium (MHI) at $37^{\circ} \mathrm{C}$ for $24 \mathrm{~h}$ prior to seeding on to the nutrient agar and the fungal strains at $30{ }^{\circ} \mathrm{C}$ for $48 \mathrm{~h}$. The crude extract was mounted on sterile filter paper discs $(6 \mathrm{~mm}$ in diameter) with the following concentrations $(\mathrm{mg} / \mathrm{mL}) 8,4,2,1,0.5$ and 0.25 ). The discs were placed on the inoculated agar media. The treated Petri dishes were kept at $4{ }^{\circ} \mathrm{C}$ for $1 \mathrm{~h}$, and incubated at $37^{\circ} \mathrm{C}$ for $24 \mathrm{~h}$. The antibacterial activity was assessed by measuring the zone of growth inhibition surrounding the discs. Each experiment was carried out in triplicate.

\section{RESULT AND DISCUSSION}

From $\eta$-hexane extract, of the earlier parts and fruits, of $F$. vulgare Mill. Subsp. piperitum the fatty acids, hydrocarbons and sterols were identified. The furocoumarins imperatorin, psoralen, bergapten, xanthotoxin and isopimpinellin were isolated from the methylene chloride extract. The flavonoids isorhamnetin $3-O-\alpha$-rhamnoside, quercetin and kaempferol were isolated from the ethyl acetate extract, where as quercetin 3-O-rutinoside, kaempferol 3-O-rutinoside and quercetin 3-O- $\beta$ glucoside were isolated from the methanol extract ${ }^{32}$. The crude $\eta$-hexane, methylene chloride, ethyl acetate and methanol extracts of this plant showed antinociceptive and anti-inflammatory activity ${ }^{32}$, however, to the best of our knowledge there are no reports about antimicrobial activity of the methylene chloride crude extract from the earlier parts of $F$. vulgare . In the current study, the methylene chloride crude extract from the earlier parts of $F$. vulgare was evaluated for its antimicrobial activity and seven oxygenated monoterpenes were isolated for the first time.

3.1 Structural Elucidation of Compounds 1-7.

Compound 1 was obtained as colorless oil. Its HR-EI-MS showed a molecular-ion peak $[\mathrm{M}+\mathrm{H}]^{+}$at $m / z 205.0536\left(\left[\mathrm{C}_{10} \mathrm{H}_{20} \mathrm{O}_{4}+\mathrm{H}\right]^{+}\right)$, and the EIMS gave a molecular-ion peak at $\mathrm{m} / \mathrm{z} 204$ and fragment-ion peaks at $\mathrm{m} / \mathrm{z}$ $186\left(\left[\mathrm{M}-\mathrm{H}_{2} \mathrm{O}\right]^{+}\right), 168\left(\left[\mathrm{M}-2 \mathrm{H}_{2} \mathrm{O}\right]^{+}\right), 153\left(\left[\mathrm{M}-2 \mathrm{H}_{2} \mathrm{O}-\mathrm{Me}\right]^{+}\right), 125\left(\left[\mathrm{M}-2 \mathrm{H}_{2} \mathrm{O}-\right.\right.$ isopropyl $\left.]^{+}\right)$, and $107\left(\left[\mathrm{M}-3 \mathrm{H}_{2} \mathrm{O} \text {-isopropyl }\right]^{+}\right)$, corresponding to a molecular formula of $\mathrm{C}_{10} \mathrm{H}_{20} \mathrm{O}$. The IR spectrum of $\mathbf{1}$ showed an obvious absorption band for $\mathrm{OH}$ groups at $3420 \mathrm{~cm}^{-1}$. From further spectral data, the structure of 1 was deduced to be rel-(1R,2S,3R,4R,6S)-p-menthane-1,2,3,6-tetrol. The structure of 1 was determined from careful investigation of the 1D and 2D NMR measurements. ${ }^{1} \mathrm{H}$ - and ${ }^{13} \mathrm{C}$-NMR spectra of $\mathbf{1}$ are shown in Tables 1 and 2, respectively. In its ${ }^{13} \mathrm{C}-\mathrm{NMR}$ spectrum, compound $\mathbf{1}$ shows ten carbon signals and the DEPT experiments indicated that these signals are corresponding to: three methyl groups, one methylene groups, five methine groups including three attached to oxygen appeared at $\mathrm{d}_{\mathrm{C}} 76.7,68.9$ and 72.9 for (C-2, C-3 and $\mathrm{C}-6)$, and one quaternary carbon atom. In the ${ }^{1} \mathrm{H}-\mathrm{NMR}$ spectrum of $\mathbf{1}$, the three methyl groups appeared at $\delta_{\mathrm{H}} 1.39(s), 0.92(d, J=7.2 \mathrm{~Hz})$, and 0.78 $(d, J=7.2 \mathrm{~Hz})$, and out of the five methine protons, three were OCH signals at $\delta_{\mathrm{H}} 3.69(d, J=9.3 \mathrm{~Hz}), 3.95(d d, J=9.3,11.4 \mathrm{~Hz})$, and $3.77(t, J=2.4 \mathrm{~Hz})$. The signal of the quaternary $\mathrm{C}$-atom was at $\mathrm{d}_{\mathrm{C}} 74.6$ in the ${ }^{13} \mathrm{C}$-NMR spectrum. Thus, compound 1 was a menthane monoterpene derivative with four $\mathrm{OH}$ groups. ${ }^{33}$ The ${ }^{1} \mathrm{H}-{ }^{1} \mathrm{H}$ COSY cross-peaks at $\delta_{\mathrm{H}} 3.95(\mathrm{H}-3) / \delta_{\mathrm{H}} 3.69(\mathrm{H}-2)$, and $\delta_{\mathrm{H}} 1.97(\mathrm{H}-$ 4), $\mathrm{H}-4 / \mathrm{H}-3, \delta_{\mathrm{H}} 1.59$ and $1.77(\mathrm{H}-5)$, and $\delta_{\mathrm{H}} 2.30(\mathrm{H}-8)$, and $\delta_{\mathrm{H}} 3.77(\mathrm{H}-6) / \mathrm{H}-5$, and the HMBC correlations (Fig. 1) of a sharp singlet methyl at $\delta_{\mathrm{H}} 1.39(\mathrm{H}-7)$ with $\delta 74.6(\mathrm{C}-1), 76.7(\mathrm{C}-2)$, and $72.9(\mathrm{C}-6)$ as well as other HMBC longrange correlations indicated that the four $\mathrm{OH}$ groups were located at $\mathrm{C}-1$, $\mathrm{C}-2, \mathrm{C}-3$, and $\mathrm{C}-6$, and the $\mathrm{Pr}$ group at $\mathrm{C}-4$, thus establishing the p-menthane1,2,3,6-tetrol structure. The relative configuration of $\mathbf{1}$ was determined by the ${ }^{1} \mathrm{H},{ }^{1} \mathrm{H}$-coupling pattern of the ring protons. The large Js of $\mathrm{H}-3$ with $\mathrm{H}-2$ and $\mathrm{H}-4(J(3,2)=9.3 \mathrm{~Hz}, J(3,4)=11.4 \mathrm{~Hz})$ showed that $\mathrm{H}-2, \mathrm{H}-3$, and $\mathrm{H}-4$ were axial protons, and the small $J \mathrm{~s}$ of H-6 with Hax-5 and Heq- $5(J(6,5 \mathrm{ax})=J(6$, $5 \mathrm{eq})=2.4 \mathrm{~Hz}$ ) were characteristic for an equatorial H-6 (Fig.2). The relative configuration at $\mathrm{C}-1$ was determined from NOE experiments: irradiation of the methyl signal at $\delta_{\mathrm{H}} 1.39(\mathrm{Me}-7)$ enhanced the signal at $\delta_{\mathrm{H}} 3.69(\mathrm{H}-2)$. Therefore, the configuration $r e l-(1 R, 2 S, 3 R, 4 R, 6 S)$ was deduced.

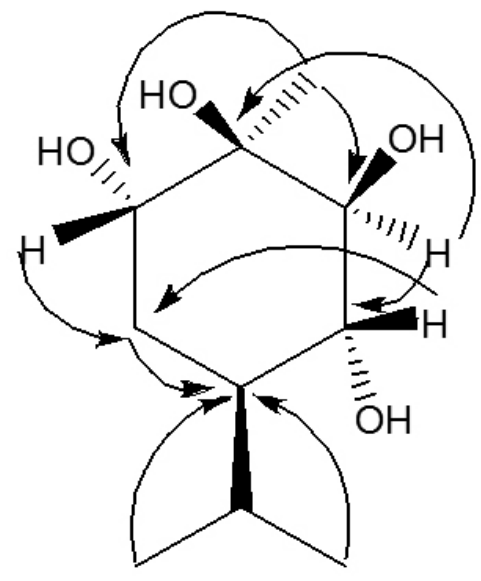

Figure 1. Selected HMBC correlations (H-C) of compound 1

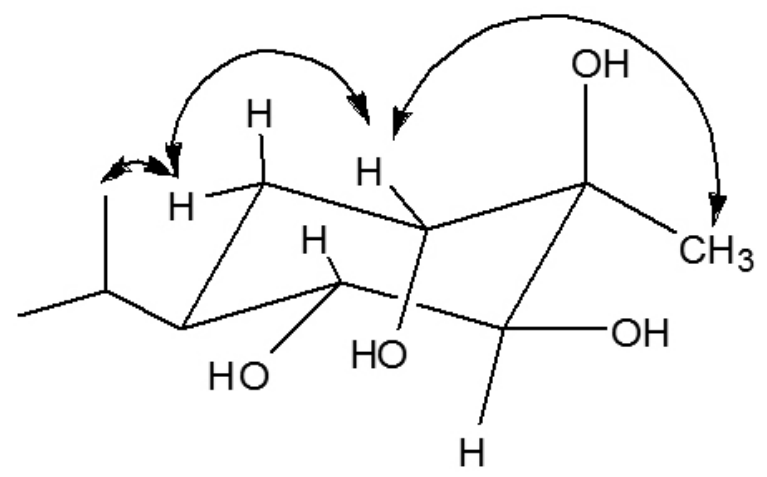

Figure 2. Important NOE correlations of compound 1.

Compound 2 was obtained as colorless oil. Its HR-EI-MS showed a molecular-ion peak $[\mathrm{M}+\mathrm{H}]^{+}$at $m / z 171.13\left(\left[\mathrm{C}_{10} \mathrm{H}_{18} \mathrm{O}_{2}+\mathrm{H}\right]^{+}\right)$, and the EI-MS gave a fragment-ion peaks at $\mathrm{m} / z 152\left(\left[\mathrm{M}-\mathrm{H}_{2} \mathrm{O}\right]^{+}\right), 134\left(\left[\mathrm{M}-2 \mathrm{H}_{2} \mathrm{O}\right]^{+}\right), 119$ $\left(\left[\mathrm{M}-2 \mathrm{H}_{2} \mathrm{O}-\mathrm{Me}\right]^{+}\right)$, and $91\left(\left[\mathrm{M}-2 \mathrm{H}_{2} \mathrm{O}-\text { isopropyl }\right]^{+}\right)$, corresponding to a molecular formula of $\mathrm{C}_{10} \mathrm{H}_{18} \mathrm{O}_{2}$. The IR spectrum of $\mathbf{2}$ showed an obvious absorption band for $\mathrm{OH}$ groups at $3420 \mathrm{~cm}^{-1}$. From further spectral data, the structure of 2 was deduced to be rel $(l R, 4 S, 6 R)$-p-menthane-3,6-diol. The structure of 2 was determined from careful investigation of the 1D and 2D NMR measurements. ${ }^{1} \mathrm{H}$ - and ${ }^{13} \mathrm{C}-\mathrm{NMR}$ spectra of $\mathbf{2}$ are shown in Tables 1 and 2 , respectively. The ${ }^{13} \mathrm{C}$-NMR spectrum of $\mathbf{2}$ displayed ten carbon signals and the DEPT experiments indicated these signals are corresponding to: three methyl groups, one methylene groups, five methine groups including two attached to oxygen appeared at $d_{C} 69.40$ and 71.07 for (C-3 and C-6) and one quaternary carbon atom. In the ${ }^{1} \mathrm{H}-\mathrm{NMR}$ spectrum, the three methyl groups appeared at $\delta_{\mathrm{H}} 1.80(s), 0.90(d, J=6.5 \mathrm{~Hz})$, and $0.99(d, J=6.5 \mathrm{~Hz})$, and out of the five methine protons, two were $\mathrm{OCH}$ signals at $\delta_{\mathrm{H}} 4.08(\mathrm{~d} d, J=2.0,9.0 \mathrm{~Hz})$ and $4.19(d d, J=3.0,8.0 \mathrm{~Hz})$. The signal of the quaternary $\mathrm{C}$-atom was at $\mathrm{d}_{\mathrm{C}} 139.13$ in the ${ }^{13} \mathrm{C}$-NMR spectrum. Thus, compound 2 was a menthane monoterpene derivative with two $\mathrm{OH}$ groups. Therefore, the configuration $\operatorname{rel}(l R, 4 S, 6 R)-p$ menthane-3,6-diol was deduced ${ }^{34,35}$. 
Table 1: ${ }^{1} \mathrm{H}$ NMR spectroscopic data for $1-7\left(500 \mathrm{MHz}, \mathrm{CDCl}_{3}\right)$

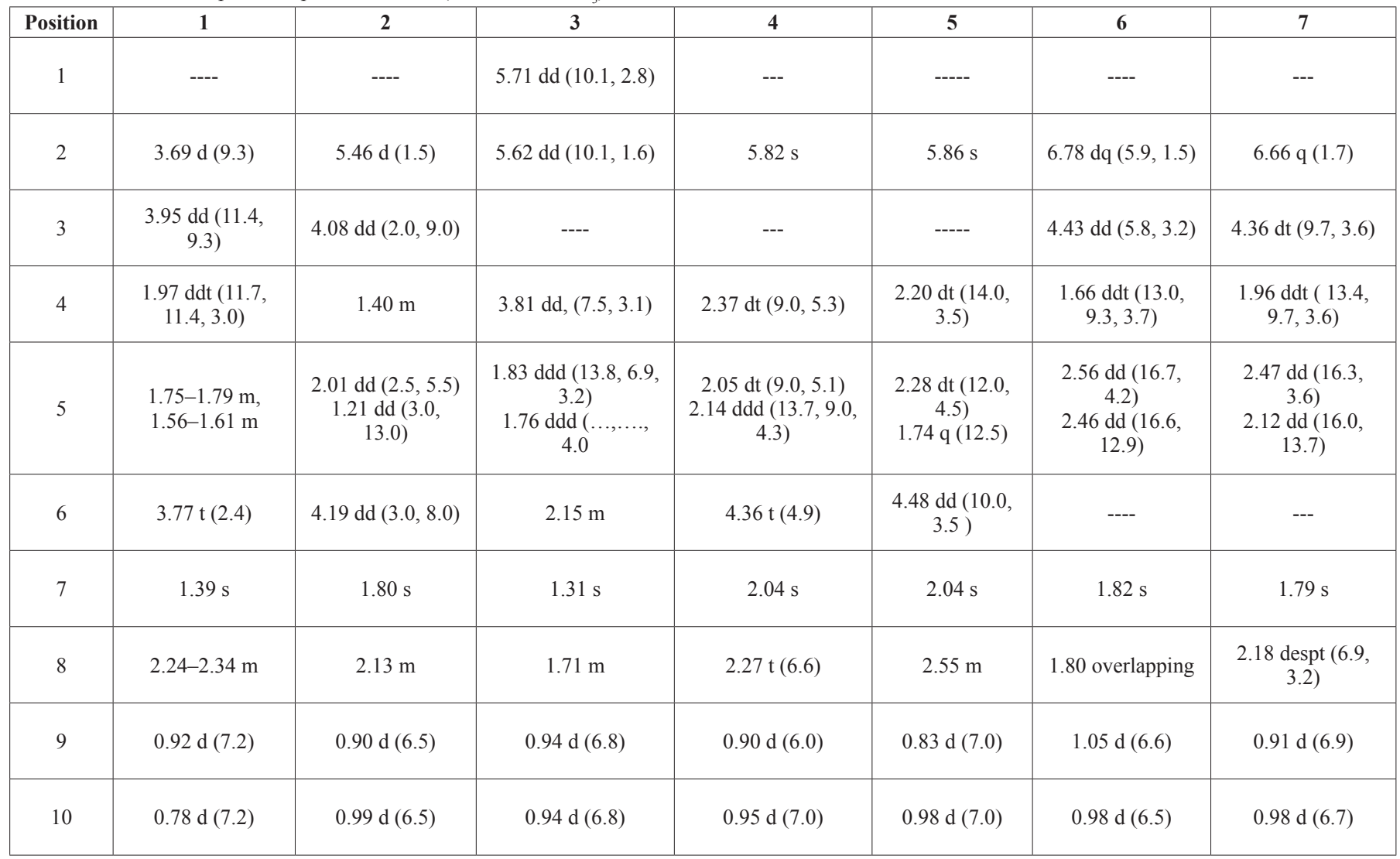

Table 2: ${ }^{13} \mathrm{C}$ NMR spectroscopic data for 1-7 $\left(125 \mathrm{MHz}, \mathrm{CDCl}_{3}\right)^{\mathrm{a}}$

\begin{tabular}{|c|c|c|c|c|c|c|c|}
\hline Position & $\mathbf{1}$ & $\mathbf{2}$ & $\mathbf{3}$ & $\mathbf{4}$ & $\mathbf{5}$ & $\mathbf{6}$ & $\mathbf{7}$ \\
\hline $\mathrm{C}-1$ & $74.56 \mathrm{~s}$ & $139.13 \mathrm{~s}$ & $132.20 \mathrm{~d}$ & $158.8 \mathrm{~s}$ & $162.6 \mathrm{~s}$ & $137.3 \mathrm{~s}$ & $135.3 \mathrm{~s}$ \\
\hline $\mathrm{C}-2$ & $76.72 \mathrm{~d}$ & $128.76 \mathrm{~d}$ & $132.00 \mathrm{~d}$ & $127.4 \mathrm{~d}$ & $127.5 \mathrm{~d}$ & $142.9 \mathrm{~d}$ & $148.2 \mathrm{~d}$ \\
\hline $\mathrm{C}-3$ & $68.86 \mathrm{~d}$ & $69.40 \mathrm{~d}$ & $70.91 \mathrm{~s}$ & $200.6 \mathrm{~s}$ & $199.4 \mathrm{~s}$ & $64.3 \mathrm{~d}$ & $69.2 \mathrm{~d}$ \\
\hline $\mathrm{C}-4$ & $41.43 \mathrm{~d}$ & $48.13 \mathrm{~d}$ & $73.53 \mathrm{~d}$ & $48.3 \mathrm{~d}$ & $51.0 \mathrm{~d}$ & $46.0 \mathrm{~d}$ & $50.1 \mathrm{~d}$ \\
\hline $\mathrm{C}-5$ & $26.77 \mathrm{~d}$ & $31.81 \mathrm{t}$ & $28.79 \mathrm{t}$ & $32.4 \mathrm{t}$ & $32.7 \mathrm{t}$ & $36.9 \mathrm{t}$ & $36.3 \mathrm{t}$ \\
\hline $\mathrm{C}-6$ & $72.95 \mathrm{~d}$ & $71.07 \mathrm{~d}$ & $38.38 \mathrm{~d}$ & $67.4 \mathrm{~d}$ & $70.5 \mathrm{~d}$ & $200.1 \mathrm{~s}$ & $199.8 \mathrm{~s}$ \\
\hline $\mathrm{C}-7$ & $23.89 \mathrm{q}$ & $21.00 \mathrm{q}$ & $23.63 \mathrm{q}$ & $26.4 \mathrm{q}$ & $25.6 \mathrm{q}$ & $28.5 \mathrm{q}$ & $26.4 \mathrm{q}$ \\
\hline $\mathrm{C}-8$ & $27.84 \mathrm{~d}$ & $26.42 \mathrm{~d}$ & $31.9 \mathrm{~d}$ & $19.0 \mathrm{~d}$ & $17.5 \mathrm{~d}$ & $20.2 \mathrm{~d}$ & $16.6 \mathrm{~d}$ \\
\hline $\mathrm{C}-9$ & $20.92 \mathrm{q}$ & $16.63 \mathrm{q}$ & $19.76 \mathrm{q}$ & $20.6 \mathrm{q}$ & $20.3 \mathrm{q}$ & $20.5 \mathrm{q}$ & $20.5 \mathrm{q}$ \\
\hline $\mathrm{C}-10$ & $14.96 \mathrm{q}$ & $18.50 \mathrm{q}$ & $19.88 \mathrm{q}$ & $20.9 \mathrm{q}$ & $19.4 \mathrm{q}$ & $15.6 \mathrm{q}$ & $15.3 \mathrm{q}$ \\
\hline
\end{tabular}

${ }^{a}$ Multiplicity was determined by DEPT experiments (s, quaternary; $d$, methine; $t$, methylene; $q$, methyl).

Compound 3 was obtained as colorless needles. The molecular formula was assigned as $\mathrm{C}_{10} \mathrm{H}_{18} \mathrm{O}_{2}$ by the $\left.\left.[\mathrm{M}+\mathrm{H}]\right]^{\dagger}\right\rceil$ peak at $\mathrm{m} / \mathrm{z} 171.1324$ in its HREI-MS and the NMR spectral data. The IR spectrum showed the presence of hydroxyl groups $\left(3450 \mathrm{~cm}^{-1}\right), 2961,2932,2874,1460,1369$, and 1261. Both ${ }^{1} \mathrm{H}$ NMR and ${ }^{13} \mathrm{C}$ NMR spectra (10 carbons including $3 \times \mathrm{CH}_{3}, 1 \times \mathrm{CH}_{2}, 5 \times \mathrm{CH}, 1 \times \mathrm{C}$ ), showed the presence of an isopropyl at $\mathrm{d}_{\mathrm{H}} 0.94(6 \mathrm{H}, d, \mathrm{~J}=6.8 \mathrm{~Hz}), 2.18(1 \mathrm{H}$, despt, $\mathrm{J}=6.9,3.2 \mathrm{~Hz})$ and $\mathrm{d}_{\mathrm{C}} 19.76\left(\mathrm{CH}_{3}\right), 19.88\left(\mathrm{CH}_{3}\right), 31.90(\mathrm{CH})$, a singlet methyl at $\mathrm{d}_{\mathrm{H}} 1.31(3 \mathrm{H}, \mathrm{s})$ and $\mathrm{d}_{\mathrm{C}} 23.63\left(\mathrm{CH}_{3}\right)$, one oxymethine at $\mathrm{d}_{\mathrm{H}} 3.81(\mathrm{dd}, \mathrm{J}$ $=7.5,3.1 \mathrm{~Hz})$ and $\mathrm{d}_{\mathrm{C}} 73.53(\mathrm{CH})$, and two olefinic methines at $\mathrm{d}_{\mathrm{H}} 5.71(\mathrm{dd}, \mathrm{J}=$ $10.1,2.8 \mathrm{~Hz}), 5.62(d d, \mathrm{~J}=10.1,1.6 \mathrm{~Hz})$ and a quaternary carbon at $\mathrm{d}_{\mathrm{C}} 70.91$ (C). Analysis of the overall NMR spectral data, suggested that compound 3 could be a monoterpenoid of p-methene with two hydroxyl groups. The ${ }^{1} \mathrm{H}-{ }^{1} \mathrm{H}$
COSY spectrum established the correlation of the cyclohexane ring: $\mathrm{CH}(1)$ $\mathrm{CH}$ (2), $\mathrm{CH}$ (4), $\mathrm{CH}_{2}(5), \mathrm{CH}$ (6). In the HMBC spectrum, correlations of $\mathrm{H}-7$ with $\mathrm{C}-4\left(\delta_{\mathrm{c}} 73.53\right), \mathrm{C}-2\left(\delta_{\mathrm{c}} 132.00\right)$ and $\mathrm{C}-3\left(\delta_{\mathrm{c}} 70.91\right), \mathrm{H}-1$ with $\mathrm{C}-8\left(\delta_{\mathrm{c}} 31.9\right)$ and $\mathrm{C}-3\left(\delta_{\mathrm{C}} 70.91\right)$, and $\mathrm{H}-9$ and $\mathrm{H}-10$ with $\mathrm{C}-6\left(\delta_{\mathrm{C}} 38.38\right)$ and $\mathrm{C}-8\left(\delta_{\mathrm{C}} 31.9\right)$ were shown. So the structure of $\mathbf{3}$ was elucidated as 3,4-dihydroxy-p-menth1 -ene. ${ }^{36}$ The relative stereochemistry of $\mathbf{3}$ was determined by the coupling constants and NOE difference spectra.

Compounds $\mathbf{4}$ and $\mathbf{5}$ exhibited similar ${ }^{1} \mathrm{H}$ and ${ }^{13} \mathrm{C}$-NMR spectra with those of compound 2. That revealed the presence of another menthane monoterpene derivative but differ in only a few aspects to the one recorded for $\mathbf{2}$, these differences included absence of oxygenated proton signal at C-3 
and appearance of carbon signal sat $\delta_{\mathrm{C}} 200.60$ and 199.40 , which revealed the presence of a keto-group at C-3.

The relative stereochemistry of $\mathbf{4}$ and $\mathbf{5}$ was determined by the coupling constants and NOE difference spectra were shown. So the structure of 4 and 5 were elucidated as $(4 R, 6 S)$-6-hydroxypiperitone (4) and $(4 R, 6 R)-6$ hydroxypiperitone $(\mathbf{5})^{37,38}$.

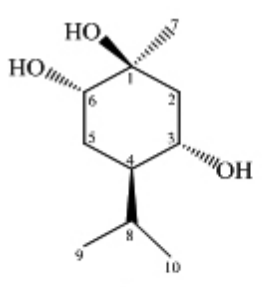

1<smiles>CC1=C[C@@H](O)C(C(C)C)C[C@@H]1O</smiles>

2

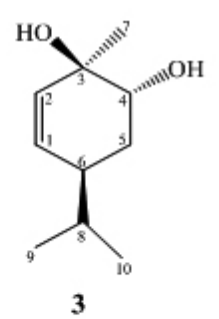

3<smiles>[R]C1CC(C(C)C)C(=O)C=C1C</smiles>

$4 \mathrm{R}=\alpha-\mathrm{OH}$

$5 \mathrm{R}=\beta-\mathrm{OH}$<smiles>[R]C1C=C(C)C(=O)CC1C(C)C</smiles>

$6 \mathrm{R}=\alpha-\mathrm{OH}$

$7 \mathrm{R}=\beta-\mathrm{OH}$
Figure 3. Oxygenated monoterpenes (1-7) from $F$. vulgare
Also Compounds 6 and 7 exhibited similar ${ }^{1} \mathrm{H}$ and ${ }^{13} \mathrm{C}-\mathrm{NMR}$ spectra with those of compound $\mathbf{2}$. That revealed the presence of another menthane monoterpene derivative but differ in only a few aspects to the one recorded for $\mathbf{2}$, these differences included absence of oxygenated proton signal at C-2 and appearance of carbon signals at $\delta_{\mathrm{C}} 200.10$ and 199.80 due to the presence of a keto-group at C-3.

The relative stereochemistry of $\mathbf{4 , 5}$ was determined by the coupling constants and NOE difference spectra were shown. So the structure of $\mathbf{4}$ and 5 were elucidated as $(4 R, 3 S)$-3-hydroxypiperitone 6 and $(4 R, 3 R)-3$ hydroxypiperitone 7 .

\subsection{Antimicrobial Activity.}

The antimicrobial activities and toxicity of terpenes have been documented, but their modes of action are complex and still in some cases unknown, considering the large number of different groups of chemical compounds present .It is most likely that their antimicrobial properties are not attributable to one specific mechanism, because of other targets in the cell. Oxygenated monoterpenes such as menthol and aliphatic alcohols were reported to possess strong to moderate activities against several bacteria ${ }^{39}$. The $\mathrm{CHCl}_{3}$ extracts of the stems of $F$. vulgare showed significant antimicrobial activity against the bacteria and fungi ${ }^{40}$. In addition, it was observed that the essential oil and seed extracts of $F$. vulgare exhibited different degree of antimicrobial activities depending on the dose applied ${ }^{41}$. Therefore, fennel oil could be a source of pharmaceutical materials required for the preparation of new therapeutic and antimicrobial agents. Due to these data we were interested to study antibacterial activity of the crude extract $\left(\mathrm{CH}_{2} \mathrm{Cl}_{2} / \mathrm{MeOH}, 1: 1 \mathrm{v} / \mathrm{v}\right)$ containing monoterpenes compounds from $F$. vulgare against both standards and isolated strains bacteria together with some fungi using the disc diffusion method.

The diffusion test was applied to nine, six bacterial and three fungal, strains. The results are summarized in Table 3 which showed that the crude extract $\left(\mathrm{CH}_{2} \mathrm{Cl}_{2} / \mathrm{MeOH} 1: 1\right)$ from $F$. vulgare prevented the growth of all the tested microorganisms with an inhibition zone medium diameter increasing proportionally with the concentration of the tested samples. The obtained inhibition varied from 6.00 to $15.00 \mathrm{~mm}$ with a highest inhibition zone recorded with $P$. vulgaris $(11-15 \mathrm{~mm})$. Nevertheless the fungi Aspergillus Sp. displayed very high inhibition diameter even with low concentration of $0.25 \mathrm{mg} / \mathrm{mL}$ $(6 \mathrm{~mm}$ and $11.6 \mathrm{~mm})$. It should be mentioned that there are no background study on $F$. vulgare terpenes except for some coumarin compounds such as Scopoletin, bergapen, psolaren on A. niger and E. coli ${ }^{40}$.

Table 3: Antimicrobial activity of crude extract $\left(\mathrm{CH}_{2} \mathrm{Cl}_{2} / \mathrm{MeOH} 1: 1\right)$ at different concentrations on six bacterial strains.

\begin{tabular}{|c|c|c|c|c|c|c|}
\hline \multirow{2}{*}{$\begin{array}{l}\text { Crude extract conc. (mg/ } \\
\text { Microorganism }\end{array}$} & \multicolumn{6}{|c|}{ Inhibition zone $(\mathrm{mm}) \pm$ standard deviation } \\
\hline & 0.25 & 0.5 & 1.0 & 2.0 & 4.0 & 8.0 \\
\hline E.coli (ATCC 25922) & $10.0 \pm 10$ & $10.0 \pm 0.0$ & $10.33 \pm 0.57$ & $10.66 \pm 0.57$ & $12.5 \pm 1.80$ & $12.5 \pm 0.86$ \\
\hline P. merabilis & $6.0 \pm 0.0$ & $6.0 \pm 0.0$ & $7.50 \pm 0.86$ & $7.50 \pm 1.80$ & $10.0 \pm 2.0$ & $10.66 \pm 1.15$ \\
\hline P. vulgaris & $11.0 \pm 2.64$ & $11.20 \pm 1.0$ & $11.5 \pm 2.17$ & $13.0 \pm 1.0$ & $13.66 \pm 2.30$ & $15.0 \pm 2.00$ \\
\hline S. epidemidis & $6.0 \pm 0.0$ & $6.0 \pm 0.0$ & $6.66 \pm 1.52$ & $10.0 \pm 0.0$ & $12.50 \pm 1.47$ & $12.50 \pm 1.47$ \\
\hline S. saprophyticus & $6.0 \pm 0.0$ & $7.33 \pm 0.81$ & $10.0 \pm 0.0$ & $10.0 \pm 1.0$ & $10.66 \pm 1.15$ & $10.66 \pm 1.15$ \\
\hline S. blanc (ATCC 27853) & $7.50 \pm 0.86$ & $7.50 \pm 0.86$ & $7.50 \pm 0.86$ & $8.0 \pm 1.00$ & $8.0 \pm 1.00$ & $1.66 \pm 1.15$ \\
\hline A. versicolor & $6.66 \pm 1.15$ & $8.0 \pm 0.0$ & $11.33 \pm 0.81$ & $11.33 \pm 0.81$ & $11.33 \pm 1.80$ & $21.0 \pm 0.86$ \\
\hline A. fumigatus & $11.66 \pm 1.15$ & $15.33 \pm 0.57$ & $15.33 \pm 0.86$ & $15.33 \pm 0.57$ & $16.66 \pm 2.0$ & $20.0 \pm 1.15$ \\
\hline P. camemberti & $9.0 \pm 1.00$ & $14.0 \pm 0.0$ & $14.33 \pm 0.81$ & $14.33 \pm 0.81$ & $14.33 \pm 1.00$ & $14.33 \pm 0.57$ \\
\hline
\end{tabular}


In general, crude extract containing this monoterpenes exhibited stronger antifungal activity than bacteria strains. The antimicrobial activity of the crude extract of F.vulgare can be attributed to the content of oxygenated monoterpenes constituents, since there is a relationship between the chemical structures and their antimicrobial activities. Although the mechanism of action of terpenes is not fully understood, it is thought to involve membrane disruption by the lipophilic compounds ${ }^{42,43}$.

\section{CONCLUSIONS}

Our results of antimicrobial assays justified and supported partly the popular usage of the all organs especially seeds as traditional remedies for some infections. It was of interest to note that the strong antimicrobial activity of the crude extract of $F$. vulgare against clinical and standard microorganisms, especially $S$. saprophyticus and E. coli which were established as major pathogens responsible for a wide variety of infection, suggested that the crude extract containing monoterpenes could be a new medicinal resource for antibacterial agents.

\section{REFERENCES}

1. G. Cao, R. L. Prior, Clinical Chemistry, 44, 1309-1315, (1998).

2. I. I. Koleva, H. A. G. Niederlander, T. A. Van Beek, Analytical Chemistry, 73, 3373-3381, (2001).

3. D. Mantle, J. G. Anderton, G. Falkous, M. Branes, P. Jones, E. K. Perry, Comprehensive Biochemistry and Physiology, 121, 385-391, (1998).

4. C. Soler-Rivas, J. C. Espin, H. J. Wichers, Phytochemical Analysis, 11, 330-338.

5. A. L. Branen, Journal of American Oil Chemical Society, 52, 59-63, (1975).

6. N. Ito, S. Fukushima, H. Tsuda, Critical Review Toxicology, 15, 109$150,(1985)$

7. L. R. Beuchat, Antimicrobial properties of spices and their essential oils. In V. M. Dillon \& R. G. Board (Eds.), Natural antimicrobial system and food preservation, 1994; pp. 167-180. Wallingford, UK: CAB International.

8. D. E. Conner, Naturally occurring compounds. In P. M. Davidson, A. L. Branen (Eds.), Antimicrobials in food, 1993; pp. 441-468. New York: Marcel Dekker.

9. L. Shelef, Journal of Food Safety, 6, 29-44, (1983).

10. G. Singh, S. Maurya, C. Catalan, M. P. Lampasoma, Journal of Agriculture and Food Chemistry, 52, 3292-3296, (2004).

11. A. Velluti, V. Sanchis, A. J. Ramos, J. Egido, S. Marin, International Journal of Food Microbiology, 89, 145-154, (2003).

12. L. A. Zaika, Journal of Food Safety, 9, 97-118, (1988).

13. H. B. Forster, H. Niklas, S. Lutz, Planta Med. 40, 309-319, (1980).

14. M.O.M. Tanira, A. H. Shah, A. Mohsin, A. M. Ageel, S. Qureshi, Phytotherapy Res. 10, 33-36, (1996).

15. M. Oktay, I. Gulcin, O. I. Kufrevioglu, Lebensm. Wiss. U. Technol. 36, 263-271, (2003).

16. D. Beaux, J. Fleurentin, F. Mortier, Phytotherapy Research, 11, 320-322, (1997).

17. M. Patra, S. K. Shahi, G. Midgely, A. Dikshit, Flavour Fragrance Journal, 17, 91-94, (2002).

18. A. Husain, Status report on aromatic and essential oil-bearing plants in NAM countries. Publication and Information Directorate (CSIR), New Delhi, 83, (1994).

19. J. A. P. Coelho, A. P. Pereira, R. L. Mendes, A. M. F. Palavera, Flavour Fragrance Journal, 18, 316-319, (2003).

20. M. Marotti, V. Dellacecca, R. Piccaglia, E. Giovanelli, D. Palevitch, J. E. Simon, Acta Horticulture, 331, 63-69, (1993).

21. B. Muckensturm, D. Foechterlen, J. P. Reduron, P. Danton, M. Hildenbrand, Biochemical Systematic and Ecology, 25, 353-358, (1997).

22. G. Singh, I. P. S. Kapoor, S. K. Pandey, U. K. Singh, R. K. Singh,. Phytotherapy Research, 16, 680-682, (2002).

23. G. Ruberto, M.T. Baratta, S.G. Deans, H. J. D. Dorman, Planta Med. 66, 687-693, (2000).

24. H. Ozbek, S. Ugras, H. Dulger, I. Bayram, I. Tuncer, G. Ozturk, A. Ozturk, Fitoterapia , 74, 317-319, (2003).

25. R. Piccaglia, M. Marotti, J. Agric. Food Chem. 49, 239-244, (2001).

26. A. Badoc, G. Deffieux, A. Lamarti, G. Bourgeois, J. P. Carde, Oil Res. 6, 333-336, (1994).
27. S. Damianova, A. Stoyanova, A. Konakchiev, I. Djurdjev, J. Essent. OilBearing Plants. 7, 247-249, (2004).

28. M. Ono, Y. Ito, T. Ishikawa, J. Kitajima, Y. Tanaka, Y. Niiho, T. Nohara, Chem. Pharm. Bull. 44, 337-342, (1996).

29. A. M. Nyemba, T.N. Mpondo, S. F. Kimbu, J. D. Connolly, Phytochemistry, 39, 895-898, (1995).

30. P. Quezel, S. Santa, Nouvelle flore de 1'Algerie et regions désertiques et Méridionales, TomeII. Edition, CNRS, Paris, (1963).

31. B. F. Carbonnelle, A. Denis, G. Marmonier, P. Rivargues, Bacteriologie medicale-techniques usuelles, 1987; pp. 224-243.

32. M. I. Nassar, E.A. Aboutabl, Y.A. Makled, E.A. El-Khrisy, A.F. Osman, Rev. Latinoamer. Quím. 38, 103-112 (2010).

33. A. A. Ahmed, J. Nat. Prod., 63, 989, (2000).

34. J. De Pascual Teresa, I. S. Bellido, C. Torres, B. A. Sastre, M. Grande, Phytochemistry, 20, 163, (1981).

35. R. Maria Del, M. Cuenca, C. A. N. Catalan, J. G. Diaz, W. Herz, J. Nat. Prod., 54, 1162, (1991).

36. Lai-King Sy, G. D. Brown, Phtochemistry, 45, 537-544, (1997).

37. H. L. De Pooter, L. F. De Buyck, N. M. Schamp, Phytochemistry 25 , 691, (1986).

38. J. A. Turner, W. Herz, J. Org. Chem. 42, 1895, (1977).

39. A. R. Koroch, H. R. Juliani, J. A. Zygadlo, Bioactivity of Essential Oils and Their Components New Use Agriculture and Natural Plant Products Program,Cook College, Rutgers University, 59 Dudley Rd, New Brunswick, NJ 08901, USA, 2000.

40. S. Y. Kwon, W. G. Choi, W. J. Kim, W. K. Kim, M. J. Kim, W. H. Kang, C. M. Kim., Arch pharm Res, 25, 154-157, (2002).

41. M. Gulfraz, S. Mehmood, N. Minhas, N. Jabeen, R. Kausar, K. Jabeen, G. Arshad, African Journal of Biotechnology, 7, 4364-4368, (2008).

42. M. M. Cowan, Clinical Microbiology Reviews, 12, 564-582, (1999).

43. H. J. D. Dorman, S. G. Deans, Journal of Applied Microbiology, 88, 308-316, (2000). 